\title{
Penerapan Maqashid Syariah pada Mekanisme Asuransi Syariah
}

\author{
Prima Dwi Priyatno \\ Universitas Pembangunan Nasional Veteran Jakarta \\ primadpriyatno@upnvj.ac.id \\ Lili Puspita Sari \\ Universitas Pembangunan Nasional Veteran Jakarta \\ lilipuspitasari@upnvj.ac.id \\ Isti Nuzulul Atiah \\ Universitas Sultan Ageng Tirtayasa \\ isti@untirta.ac.id
}

Received: August 6, 2020 | Accepted: August 8, 2020 | Published: August 10, 2020

\begin{abstract}
The difference of opinion about sharia insurance is still a debate among scholars to date, sharia insurance itself is a contemporary issue that becomes ikhtilaf. This study tried to see the insurance side of sharia Maqasid point of view. The implementation of Sharia Maqasid on insurance is the meeting point between the objectives of Sharia. Protection of religion in Sharia insurance is realized in the form of transactions that begin with contributions in the form of Tabarru' (donation). In addition to this there are Hajj insurance products. Sharia insurance business in the aspect of life protection is found in the things that cause mental harm, damage to limbs that cause disability or death of a person. The role of insurance on the benefit of the soul is more emphasized on the aspect of prevention (min Nahiyyati al-'adam). At the benefit of mind, insurance does not specifically protect. However, one of the human efforts to protect mind is in a way of studying. This is where insurance plays its role as an education funder. Examples of insurance products that protect our benefits are takaful insurance for student funds or scholarship insurance. In the protection of offspring, the role of insurance is more emphasized in terms of existence ( $\mathrm{min}$ Nahiyyati al-wujud) namely to realize the benefits of heirs or families left behind. Lastly, in providing protection against property, insurance provides services in response to risks of loss, loss of benefits, and legal responsibility to third parties arising from uncertain events. Examples of insurance that protect property benefits are general Takaful insurance, such as fire takful
\end{abstract}

Keywords: Sharia insurance; Maqashid Syariah; Welfare

\begin{abstract}
Abstrak
Perbedaan pendapat tentang asuransi syariah masih menjadi perdebatan dikalangan ulama hingga saat ini, Asuransi Syariah sendiri merupakan isu kontemporer yang menjadi ikhtilaf. studi ini mencoba melihat sisiasuransi dari kaca mata maqasid syariah. Implementasi maqasid syariah pada asuransi merupakan titik temu antara tujuan ditetapkannya syariah. Perlindungan agama dalam asuransi syariah direalisasikan dalam bentuk transaksi yang dimulai dengan kontribusi dalam bentuk tabarru'. Selain hal tersebut terdapat produk asuransi haji. Usaha asuransi syariah dalam aspek perlindungan jiwa terdapat pada hal-hal yang menyebabkan terancamnya jiwa, kerusakan anggota badan yang menyebabkan kecacatan a taupun kematian ses eorang. Peranan asuransi pada kemaslahatan jiwa ini lebih ditekankan pada aspek pencegahan (min nahiyyati al- 'adam). Pada kemaslahatan akal, asuransi tidak secara spesifik melindungi. Namun, salah satu upaya manusia untuk melindungi akal ialah dengan cara menuntut ilmu. Disinilah letak asuransi memainkan
\end{abstract}


perannya sebagai penyandang dana pendidikan. Contoh produk asuransi yang melindungi kemaslahatan akal adal ah asuransi takaful dana siswa atau asuransi beasiswa. Dalam perlindungan terhadap keturunan, peranan asuransi lebih ditekankan pada segi adanya (min nahiyyatial-wujud) yaitu mewujudkan kemaslahatan ahli waris atau keluarga yang ditinggal. Terakhir, dalam memberikan perlindungan terhadap harta, asuransi memberikan jasa dalam penanggulangan risiko atas kerugian, kehilangan manfaat, dan tanggung jawab hukum kepada pihak ketiga yang timbul dari peristiwa yang tidak pasti. Contoh asuransi yang melindungi kemaslahatan harta adalah asuransi takaful umum, misalnya takful kebakaran

Kata kunci: Asuransi Syariah; Maqashid Syariah; Kemaslahatan

\section{PENDAHULUAN}

Perbedaan pandangan atau kajian hukum tentang asuransi dari sudut pandang keislaman menghasilkan beberapa perbedaan hukum yang dapat kita kelompokan menjadi empat kelompok; pertama, pendapat yang menyatakan hukum berasuransi adalah syubhat secara mutlak, mereka berpandangan transaksi yang terdapat pada kegiatan asuransi merupakan kegiatan yang tidak mempunyai landasan baik dalam al-Quran maupun al-Sunnah nabi. Pendapat kedua, dikemukakan oleh Yusuf Qardlawi, Sayyid Sabiq, Abdullah al-Qalqili dan M. Bakhil al-Muthi, yang berpandangan bahwa segala bentuk asuransi adalah haram secara mutlak, diantara alasan penolakannya adalah praktek kegiatan asuransi mengandung unsur gharar, maysir dan riba, serta tidak etis membisniskan suatu kemalangan atau musibah sebagai objek berbisnis. Ketiga, kelompok yang berpandangan kebolehan berasuransi secara mutlak, diantara kelompok yang mendukung pendapat ini adalah Abdul Wahab Khalaf, M. Yusuf Musa, dan Mustafa Ahmad Zarqa. Alasan yang dikemukakan adalah bahwa, asuransi termasuk ke dalam praktik muamalah bentuk baru, dan tidak adanya nash yang melarang kegiatan asuransi, selain itu asuransi mengandung unsur saling menguntungkan dan mempunyai banyak manfaat serta adanya kesepakatan antara dua pihak dalam berasuransi. Ketiga, pendapat yang dikemukakan oleh Muhammad Abu Zahra, yaitu memperbolehkan asuransi yang bersifat sosial dan mengharamkan asuransi yang bersifat komersial, hujjah pendapat ini adala h sama dengan alasan kelompok satu, dimana asuransi yang bersifat komersial itu mengandung gharar, maysir dan riba serta tidak etis dalam membisniskan musibah yang menimpa orang lain. Namun diperbolehkan dalam asuransi yang bersifat sosial, dimana gharar dalam hal ini diperbolehkan sehingga mengeliminir maysir dan riba yang ada di dalamnya (Zuhdi, 1997).

Kehadiran asuransi syariah menjadi opsi lain bagi umat muslim khususnya dalam mengelola keuangan untuk menerapkan manajemen risiko yang mungkin akan dihadapi di masa yang akan datang, akad dan transaksi dalam asuransi syariah disesuaikan dengan akad-akad yang tidak dibolehkan atau dilarang dalam 
islam. Hal tersebut juga masih menjadi persoalan hukum dan menambah kebingungan (perdebatan) hukum untuk masyarakat secara umum, sehingga sampai saat ini, asuransi masih menjadi perdebatan hukum termasuk juga asuransi syariah, dimana ada yang membolehkan, mengharamkan dan juga mensyubhatkan bentuk dari asuransi syariah itu sendiri (Billah, 1993).

Kata asuransi sendiri tidak ditemukan dalam al-Quran maupun as-Sunah secara eksplisit. Asuransi, mulanya merupakan suatu cara dalam mempersiapkan untuk menghadapi risiko yang mungkin akan terjadi dengan kesepakatan sekelompok orang, yaitu bersepakat apabila terjadi suatu risiko pada salah satu kelompok tersebut ada yang mengalami musibah. Sejarahnya asuransi dikenal berupa asuransi kebakaran, yaitu di Eropa Barat, kemudian pada abad ke 13 dan 14 terjadi peningkatan transportasi jalur laut baik untuk mengirim barang atau pengantaran orang antar pulau sehingga berkembang pula asuransi pengangkutan laut yang berasal dari Romawi. Jenis asuransi pada saat itu yang berkembang adalah jenis asuransi kaputalis, dimana asuransi dibentuk untuk mendapatkan keuntungan dan didasarkan atas perhitungan niaga. Pada abad ke 19 barulah dikenal istilah asuransi jiwa. Kata asuransi berasal dari bahasa belanda yang biasa disebut dengan istilah assurantie (Asuransi) dan verzekering (Pertanggungan). Dalam bahasa Inggris disebut insurance, yang dalam bahasa Indonesia telah menjadi bahasa popular dan diadopsi dalam kamus besar bahasa Indonesia dengan padanan kata pertanggungan (Hasan Ali, 2004).

Asuransi syariah termasuk pada lembaga keuangan yang berbasis pada konsep syariah, pengembangan konsep syariah ini merupakan sebagai sebuah solusi dan pilihan lain dalam perkembangan konsep ekonomi ribawi, dimana konsep ribawi tersebut tidak dapat menjawab permasalahan perekonomian global yang semakin kompleks. Kehadiran asuransi syariah diharapkan dapat mewujudkan kemaslahatan manusia serta mensejahterakan perekonomian umut dengan tidak melanggar konspe syariah, dalam mewujudkan niat tersbeut maka pedoman utama dalam setiap aktifitas dan oprasional serta produk-produk yang ada pada asuransi syariah harus memperhatikan pedoman tujuan dari syariatatau disebut maqashid syariah.

Maqashid syariah merupakan visi serta tujuan diterapkannya syariah islam, dalam bidang ekonomi, islam mempunyai visi yang memegang perranan tatanan sosial untuk memberikan keadilan sosial bersamaan dengan kemakmuran ekonomi umat, oleh sebabitu syariah islam merupakan tata cara ataupun aturan hidup yang berasal dari Allah swt. Untuk menjadi pedoman hidup bagi seluruh umat manusia (Dusuki \& Abozaid, 2007). Pendekatan maqashid syariah dalam menganalisis asuransi syariah, dapat memberikan pola pikir dan gambaran secara rasional dan substansial pada aktivitas oprasional, akad dan produk-produk yang ditawarkan, sehingga diharapkan produk yang didesign dapat berkembang sesuai 
dengan kebutuhan yang berubah secara cepat sesuai perkembangan zaman, tentu dengan tujuan yang sejalan dengan maqashid syariah untuk mewujudkan kemaslahatan umat. Hal tersbut berbeda bila hanya menggunakan pendekatan fiqh yang mempunyai sifat formalistik dan tekstual (Zaki \& Cahya, 2015). Tulisan ini akan fokus pada kajian asuransi syariah melalui pendekatan indicator-indikator yang ada pada maqashid syariah, sehingga dapat mencapai kemaslahatan sebagai tujuan syariah itu dapat tercapai.

\section{TINJAUAN PUSTAKA}

\section{A. Konsep Asuransi Syariah}

Dalam bahasa Arab, asuransi dikenal dengan istilah at-ta'min, penanggung disebut mu'ammim, tertanggung disebut mu'amman lahu atau musta'min. Atta'min di ambil dari amana yang artinya memberi perlindungan, ketenangan, rasa aman, dan bebas dari rasa takut (Muhammad Syakir Sula, 2004). Dalam QS. Quraisy ayat 4, Allah SWT berfirman:

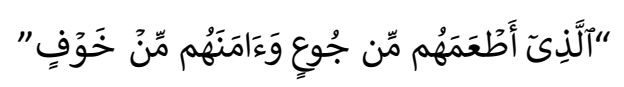

"Yang telah memberi makanan kepada mereka untuk menghilangkan lapar dan mengamankan mereka dari rasa ketakutan". Dari arti terakhir surat tersebut, dianggap paling tepat untuk mendefinisikan istilah at-ta'min, yaitu, menta'min-kan sesuatu, artinya adalah seseorang membayar/menyerahkan uang cicilan untuk agaria atau ahli warisnya mendapatkan sejumlah uang sebagaimana yang telah disepakati, atau untuk mendapatkan ganti terhadap hartanya yang hilang (Sula, 2004).

Prinsip saling menanggung, melindungi, dan saling menolong antarMuslim didasari oleh suatu riwayat Dari an-Nu'man bin Basyir ra bahwasanya Rasulullah bersabda:

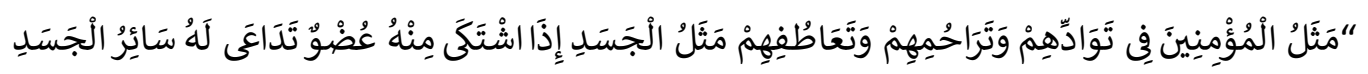

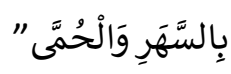

"Perumpamaan orang mukmin dalam mencintai, menyayangi dan saling menaruh simpati diantara mereka seperti satu jasad, jika ada anggota tubuh yang merasa sakit maka akan menjadikan seluruh tubuhnya ikut terjaga dan merasa sakit." (HR Muslim) 
Berdasarkan prinsip tersebut, Dewan Syariah Nasional MUI (dalam Didin Hafidhuddin, 2009) menetapkan pengertian asuransi syariah (ta'min, takaful, atau tadhamun) adalah usaha saling melindungi dan tolong-menolong di antara sejumlah orang/pihak melalui dana investasi dalam bentuk aset atau tabarru' yang memberikan pola pengembalian untuk menghadapi risiko tertentu melalui akad (perikatan) yang sesuai dengan syariah. Yang dimaksud sesuai dengan syariah adalah yang tidak mengandung gharar (ketidakpastian), maisir (perjudian), riba (bunga), zhulum (penganiyaan), risywah (suap), barang haram, dan perbuatan maksiat.

Menurut ahli figh kontemporer, Wahab az-Zuhaili (dalam Wirdyaningsih, 2005) mendefinisikan asuransi berdasarkan pembagiannya. la membagi asuransi dalam dua bentuk, yaitu at-ta'min at-ta'awuni dan at-ta'min bi qist sabit. Atta'min at-ta'awuni atau asuransi tolong menolong adalah kesepakatan sejumlah orang untuk membayar sejumlah uang sebagai ganti rugi ketika salah seorang di antara mereka mendapat kemudaratan. At-ta'min bi qist sabit atau asuransi dengan pembagian tetap adalah akad yang mewajibkan seseorang membayar sejumlah uang kepada pihak asuransi yang terdiri atas beberapa pemegang saham dengan perjanjian apabila peserta asuransi mendapatkan kecelakaan, ia diberi ganti rugi.

Asuransi syariah menurut UU Nomor 40 tahun 2014 adalah kumpulan perjanjian, yang terdiri atas perjanjian antara perusahaan asuransi syariah dan pemegang polis dan perjanjian diantara para pemegang polis, dalam rangka pengelolaan kontribusi berdasarkan prinsip syariah guna saling menolong dan melindungi dengan cara memberikan penggantian kepada peserta atau pemegang polis karena kerugian, kerusakan, biaya yang timbul, kehilangan keuntungan, atau tanggung jawab hukum kepada pihak ketiga yang mungkin diderita peserta atau pemegang polis karena terjadinya suatu pristiwa yang tidak pasti; atau memberikan pembayaran yang didasarkan pada meninggalnya peserta atau pembayaran yang didasarkan pada hidupnya peserta dengan manfaat yang besarnya telah ditetapkan dan/atau didasarkan pada hail pengelolaan dana. 
Al-Fanjari mengartikan tadhamun, takaful, at-ta'min atau asuransi syariah dengan pengertian saling menanggung atau tanggung jawab sosial. Kemudian menurut Mushtafa Ahmad Zarqa, makna asuransi secara istilah adalah kejadian, adapun metodologi dan gambarannya dapat berbeda-beda. Namun pada intinya, asuransi adalah cara atau metode untuk memelihara manusia dalam menghindari risiko (ancaman) bahaya yang beragam yang akan terjadi dalam hidupnya, perjalanan kegitan hidupnya atau aktivitas ekonominya (Muhamad Syakir Sula, 2004).

Menurut Muhaimin Iqbal (2005) asuransi syariah adalah suatu pengaturan pengelolaan risiko yang memenuhi ketentuan syariah, tolong-menolong secara mutual yang melibatkan peserta dan operator. Syariah berasal dari ketentuanketentuan di dalam al-Qur'an (firman Allah yang disampaikan kepada Nabi Muhammad SAW) dan as- Sunnah (teladan dari kehidupan Nabi Muhammad SAW).

Salah satu dasar hukum yang menjadi landasan asuransi syariah dalam alQur'an adalah pada QS. al-Hasyr ayat 18:

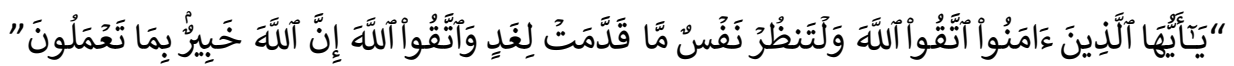

"Wahai orang-orang yang beriman! Bertakwalah kepada Allah dan hendaknya setiap orang memperhatikan apa yang telah diperbuatnya untuk hari esok (akhirat), dan bertakwalah kepada Allah. Sungguh, Allah Maha mengetahui apa yang kamu kerjakan".

Dalam firman Allah tersebut jelas bahwa Allah memerintahkan hambanya untuk senantiasa melakukan persiapan menghadapi hari esok atau masa depan. Oleh karena itu, sebagian dari kita banyak yang berusaha untuk menabung atau berasuransi untuk mempersiapkan masa depan yang kita tidak tahu akan seperti apa. Menabung dan berasuransi pada dasarnya sama, yaitu bertujuan untuk berjaga-jaga menghadapi hari esok jika terjadi sesuatu yang mendesak dan tidak terduga. Selain al-Qur'an, dasar hukum lain yang melatarbelakangi adanya asuransi adalah hadits riwayat Bukhari dan hadits riwayat at-Tirmidzi nomor 989 (Ambarniati, 2017): 


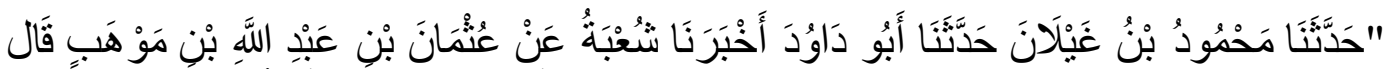

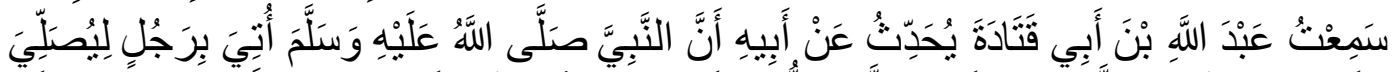

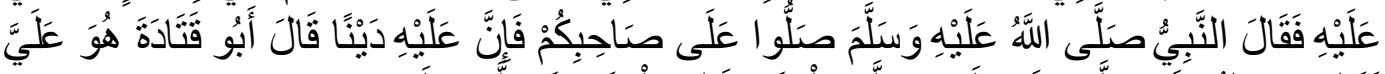

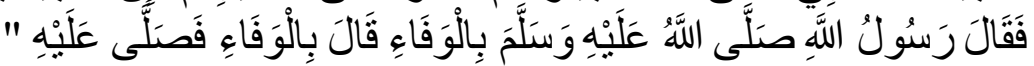

"Telah menceritakan kepada kami Mahmud bin Ghailan, telah menceritakan kepada kami Abu Daud telah mengabarkan kepada kami Syu'bah dari 'Utsman bin Abdullah bin Mauhab berkata; saya telah mendengar Abdullah bin Abu Qatadah menceritakan dari Bapaknya bahwa; Nabi shallallahu 'alaihi wasallam didatangkan padanya, seorang laki-laki agar beliau menshalatinya. Nabi shallallahu 'alaihi wasallam bersabda: "Shalatilah teman kalian ini, dia memiliki hutang." Abu Qatadah berkata; "Saya yang akan membayarnya." Rasulullah shallallahu 'alaihi wasallam bersabda: "Kamu mau melunasinya?" Dia mengiyakannya lalu beliau menshalatinya." (HR. Tirmidzi)

Sebelum adanya asuransi syariah, masyarakat lebih dulu mengenal asuransi konvensional. Meskipun berdasarkan sejarah yang ditulis oleh Gemala Dewi (2004), asuransi termasuk dalam lembaga keuangan non bank yang telah hadir pada masa awal Islam yang dikenal dengan konsep tanggung jawab bersama atau disebut dengan sistem aqilah. Akan tetapi, asuransi dalam perkembangan sejarah dunia hadir dan dibawa oleh orang-orang non muslim, sehingga secara tidak langsung dalam praktik operasionalnya terdapat unsur-unsur yang bertentangan dengan aturan Islam, seperti terdapat unsur riba, gharar, dan maisir. Jika ditinjau pula dari segi hukum perikatan Islam maka asuransi konvensional hukumnya haram, dan ini yang disepakati oleh beberapa ahli hukum Islam seperti Abdul Wahab Khalaf, Sayyid Sabiq, dan Yusuf al-Qardawi. Dengan berlandaskan bahwa hukum dari asuransi konvensional adalah haram, maka perlu suatu rumusan konsep yang dapat menghindarkan dari praktik riba, gharar, dan maisir yang semua itu diharamkan oleh Islam. Untuk itu maka dibuatlah konsep asuransi takaful atau asuransi yang berlandaskan pada asas-asas hukum Islam.

Menurut Warkum Sumitro (1997) perbedaan lain antara asuransi syariah dengan konvensional antara lain jika dilihat dari prinsip, asuransi syariah adalah takaful yakni saling tolong menolong, sedangkan asuransi konvensional adalah 
bersifat tadabuli saling tukar menukar. Kemudian dana yang terkumpul dari peserta asuransi syariah diinvestasikan berdasarkan sistem bagi hasil, dalam asuransi konvensional dana yang terkumpul diinvetasikan pada berbagai sektor dengan sistem bunga. Lalu dalam asuransi syariah, premi yang terkumpul tetap menjadi milik nasabah atau peserta asuransi, dalam asuransi konvensional premi menjadi milik hak perusahaan asuransi sendiri. Perbedaan berdasarkan operasionalnya antara lain dalam asuransi konvensional terdapat unsur komersial yang masih sangat menonjol, sedangkan dalam asuransi syariah lebih ditekankan konsep ta'awun atau saling tolong-menolong.

\section{B. Prinsip Asuransi Syariah}

Menurut Ali Zainuddin (2008:77) dalam industri asuransi, baik asuransi kerugian maupun asuransi jiwa, memiliki prinsip-prinsip yang menjadi pedoman bagi seluruh penyelenggaraan kegiatan perasuransian dimanapun berada. Prinsip syariah berdasarkan UU Nomor 40 Tahun 2014 adalah prinsip hukum Islam dalam kegiatan perasuransian berdasarkan fatwa yang dikeluarkan oleh lembaga yang memiliki kewenangan dalam penetapan fatwa di bidang syariah.

Prinsip utama asuransi syariah ialah tolong-menolong dan rasa aman antar anggota. Prinsip ini menjadikan anggota asuransi syariah sebagai suatu anggota keluarga besar yang saling tolong-menolong menjamin dan menanggung risiko antara satu anggota dengan anggota yang lain. Hal ini disebabkan transaksi yang dibuat dalam asuransi syariah adalah berdasarkan akad takafuli (saling menanggung), bukan akad tadabuli (saling menukar), yaitu pertukaran pembayaran premi dengan uang pertanggungan yang selama ini digunakan dalam asuransi konvensional. Hasan Ali (2005) menyebutkan bahwa prinsip-prinsip dasar asuransi syariah antara lain tauhid, keadilan, tolong menolong dan kerja sama, serta menghindari unsur gharar, maisir dan riba. 


\section{Konsep Maqashid Syariah}

Maqasid syari'ah berasal dari bahasa Arab, yaitu dari akar kata qashd (قصد). maqasid (مقاصد) adalah jama' atau suatu kata yang menunjukan banyak, sedangkan mufradnya adalah maqshad (مقصَذْ ) yang berarti tujuan atau target. Maqasid syari'ah terdiri dari dua unsur kata, pertama maqasid yang berarti tujuan atau tempat yang dituju (Warson, 2000). Kata yang kedua, syari'ah yang berarti jalan ke arah sumber pokok kehidupan (Zaid, 1954). Jadi secara etimologi maqasid syari'ah berarti objek atau tujuan yang dituju oleh syari'ah.

Al-Ghazali (1997) menyebutkan bahwa tujuan disyariatkannya hukum Islam adalah untuk mewujudkan kemaslahatan manusia. Kemudian al-Ghazali mendefinisikan bahwa mashlahah pada dasarnya adalah ungkapan dari menarik manfaat dan menolak mudhorot dengan maksud bahwa dengan maslahat ialah memelihara tujuan syara' atau hukum Islam, dan tujuan syara' dari mahluk itu ada lima, yaitu memelihara agama, jiwa, akal, keturunan atau kehormatan, dan harta mereka. Maka setiap hal yang mengandung upaya memelihara kelima hal prinsip ini disebut maslahah, dan setiap hal yang menghilangkan kelima prinsip ini disebut mafsadah dan menolaknya disebut maslahah.

\section{Ragam Maqashid Syariah}

Ragam maqashid syari'ah menurut Imam Syatibi terbagi kepada tiga bagian penting. yaitu dharuriyyat (primer), hajiyyat (skunder) dan tahsinat (tersier, lux). Tingkatan pertama, maqasid atau maslahat dharuriyyat adalah kebutuhan primer atau sesuatu yang mesti adanya demi terwujudnya kemaslahatan agama dan dunia, seperti beribadah, makan, minum, berpakaian, menjaga harta, menjaga jiwa, dan menjaga akal. Kemudian beliau menyatakan bahwa kemashlahatan yang menjadi tujuan syariat ini dibatasi dalam lima hal. Setiap hal yang mengandung penjagaan atas lima hal ini disebut maslahah dan setiap hal yang membuat hilangnya lima hal ini disebut mafsadah. Lima hal yang dimaksud antara lain; perlindungan terhadap agama atau hifdzu ad-diin, perlindungan terhadap jiwa atau hifdzu an-nafs, perlindungan terhadap akal atau 
hifdzu al-'aql, perlindungan terhadap keturunan atau hifdzu an-nasl, perlindungan terhadap harta atau hifdzu al-maal. Tingkatan kedua, maqasid hajiyat yaitu kebutuhan-kebutuhan sekunder, di mana jika tidak terwujudkan tidak sampai mengancam keselamatannya, namun akan mengalami kesulitan. Syariat Islam menghilangkan segala kesulitan itu. Tingkatan ketiga, maqasid tahsiniyat ialah tingkat kebutuhan yang apabila tidak terpenuhi tidak mengancam eksistensi salah satu dari lima pokok di atas dan tidak pula menimbulkan kesulitan (Al-Syatibi, 1997).

Dalam aktivitas perekonomian, khususnya kdalam pemenuhan kebutuhan manusia, mempunyai tingkatan dharuriat (primer), hajiyat (Skunder) dan tahsiniat (Tersier). Prilaku tiap individu dalam pemenuuhan akan kebutuhan kelima hal tersebut adalah maslahat, dan setiap prilaku yang mencegah atau menghilankan kelima hal tersebut adalah mafsadat. Dari telaah nash-nash syar'l, ulama sepakat bahwa diturunkannya syariah adalah untuk memenuhi kelima hajat tersebut (Syahroni \& Karim, 2016).

\section{Struktur Maqashid Syariah}
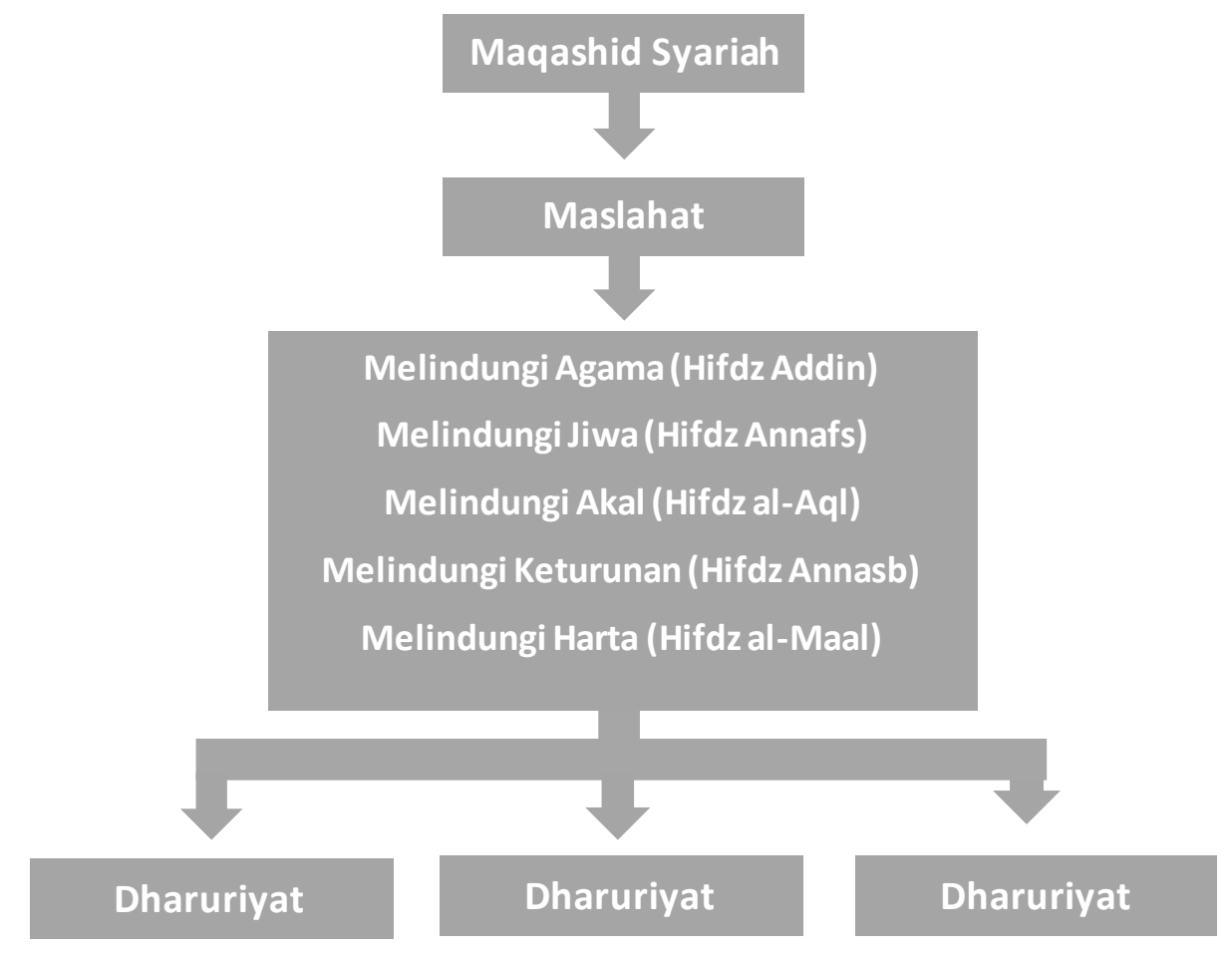


\section{PEMBAHASAN}

\section{Penerapan Maqashid Syariah dalam Asuransi Syariah}

Hakikat dari teori maqasid asy-syariah bahwa pada dasarnya tujuan dari hukum Islam adalah terwujudnya kemaslahatan bagi manusia. Menurut al-Ghazali (dalam Ismanto: 2016) menyebutkan bahwa ada lima aspek yang dilindungi oleh syara', yang dikenal dengan al-kuliyyah al-khams, meliputi agama, jiwa, akal, keturunan, dan harta. Untuk menjaga kelima aspek tersebut dapat dilakukan dengan dua cara, pertama, dari segi adanya atau keberadaannya (min nahiyyati al-wujud) yaitu dengan cara manjaga dan memelihara hal-hal yang dapat melanggengkan keberadaannya, dan kedua, dari segi tidak adanya (min nahiyyati al-'adam) yaitu dengan cara mencegah hal-hal yang menyebabkan ketiadaannya (Al-Syatibi, 1997).

\section{A. Perlindungan Terhadap Kemaslahatan Agama}

Muhammad Utsman Najati (2008) mengatakan bahwa secara fitrah, manusia memiliki kesiapan (potensi) untuk mengenal dan beriman kepada Allah. Manusia berpotensi untuk bertauhid, mendekatkan diri kepada Allah, kembali kepada-Nya dan meminta pertolongan kepada-Nya dalam menghadapi kesulitan. Wujud terlaksananya Islam bagi umat Islamadalah apabila ia mampu menjalankan rukun Islam dengan baik, yang terdiri dari membaca dua kalimat syahadat, menjalankan sholat, membayar zakat, menunaikan ibadah haji bagi yang mampu, serta menjalankan ibadah puasa.

Sebagai contoh penerapan asuransi syariah dalam memberikan perlindungan terhadap agama dapat dilihat dari pelaksanaan produk asuransi haji yang memberikan perlindungan risiko bencana yang terjadi pada jamaah haji yang sedang melaksanakan ibadah haji. Produk asuransi haji ini tertuang dalam aturan fatwa DSN-MUI No 39/DSN-MUI/X/2002 tentang asuransi haji.

Dalam perlindungan terhadap agamapun, asuransi syariah bisa merealisasikannya dalam bentuk transaksi yang dimulai dengan kontribusi dalam bentuk tabarru' (donasi). Ini dianggap sebagai kontribusi tulus seseorang untuk 
kumpulan kontribusi. Hubungan antar peserta dan kumpulan risiko (sebagaimana dikelola oleh perusahaan asuransi syariah) disebut sebagai Tabarru'. Semua kontribusi dikumpulkan dari pemegang polis atau peserta tidak dimaksudkan untuk transfer risiko seperti yang ada pada asuransi konvensional tetapi ini dimaksudkan untuk membantu mereka yang terkena musibah, yang dianggap sebagai 'ibadah' (Fisher, 2013).

Penerapan konsep serta operasional asuransi syariah juga diawasi oleh dewan pengawas syariah (DPS) yang mempunya tugas untuk mengawal dan menjadi kepanjangan tangan Dewan Pengawas Syariah (DSN-MUI), sehingga setiap aktivitas bisnis dalam asuransi syariah benar-benar menjalankan sesuai dengan tuntunan syariah, hal tersebut juga masuk pada penjagaan agama ( $h i f d z$ ad-dien).

\section{B. Perlindungan Terhadap Kemaslahatan Jiwa}

Hak pertama dan paling utama yang diperhatikan Islam adalah hak hidup. Hak yang disucikan dan tidak boleh dihancurkan kemuliaannya. Sangatlah jelas hikmah dari penciptaan manusia yakni fitrah yang diciptakan-Nya dan menjadikannya dalam bentuk yang sebaik-baiknya (Jauhar, 2010). Usaha asuransi syariah dalam aspek perlindungan kemaslahatan jiwa terletak pada hal-hal yang menyebabkan terancamnya jiwa, kerusakan anggota badan yang menyebabkan kecacatan ataupun kematian seseorang. Peranan asuransi pada kemaslahatan jiwa ini lebih ditekankan pada aspek pencegahan (min nahiyyati al- 'adam).

\section{Perlindungan Terhadap Kemaslahatan Akal}

Salah satu kelebihan manusia dibandingkan dengan mahluk lainnya ialah memiliki akal. Selain sebagai dimensi berfikir, akal juga memiliki makna kemuliaan. Maksudnya adalah orang yang menggunakan akalnya sesuai dengan petunjuk Allah SWT disebut sebagai orang yang berakal dan ketika ia istiqamah dengan hasil pemikirannya yang benar maka ia menjadi mulia dengan hakikat-hakikat yang diketahuinya tersebut sehingga mencegah pemiliknya untuk melakukan hal-hal 
buruk dan mengerjakan kemungkaran. Netta Agusti dalam Jurnal Hukum Ekonomi Syariah (2019) mengatakan bahwa menjaga dan melindungi akal bisa dilaksanakan dengan penjagaan antara akal itu sendiri dengan ujian dan bencana yang bisa melemahkan, dan merusakkannya, atau menjadikan pemiliknya sebagai sumber kejahatan dan sampah dalam masyarakat.

Dalam al-Qur'an terdapat beberapa ayat yang menegaskan tentang akal manusia, salah satunya ialah dalam QS. al-Ankabut ayat 35:

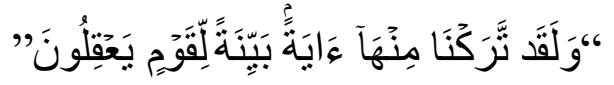

"Dan sesungguhnya Kami tinggalkan daripadanya satu tanda yang nyata bagi orang-orang yang berakal".

Pada dasarnya, asuransi tidak secara spesifik melindungi kemaslahatan akal, akan tetapi asuransi ini membantu seseorang untuk menjaga kebaradaan akal dari kerusakan. Bentuk perlindungan asuransi syariah terhadap akal adalah aspek perwujudan (min nahiyyati al-wujud). Salah satu cara manusia untuk menjaga akal dari kerusakan adalah dengan belajar atau menuntut ilmu. Meskipun proses belajar bisa dadapatkan darimana saja dan secara non formal, akan tetapi di Indonesia kegiatan belajar pada umumnya dilakukan secara formal, yaitu di sekolah maupun perguruan tinggi. Tentunya untuk memasuki sebuah institut pendidikan, seseorang harus mempunyai dana yang tidak sedikit. Akan tetapi, tak jarang seseorang tidak mampu membiayainya secara serentak karena satu atau berbagai hal. Misalnya karena orang tua meninggal, pensiun, lanjut usia, di-PHK, dan lain-lain sehingga tidak dapat membiayai putranya sebagaimana mestinya. Tentunya kondisi ini sangat menghambat seseorang untuk melanjutkan pendidikannya. Disinilah letakasuransi memainkan perannya sebagai penyandang dana pendidikan. Contoh produk asuransi yang melindungi kemaslahatan akal adalah asuransi takaful dana siswa atau asuransi beasiswa. Takaful ini bertujuan untuk perorarangan yang ditujukan kepada mereka yang bermaksud menyediakan dana pendidikan bagi putra-putrinya. 


\section{Perlindungan Terhadap Kemaslahatan Keturunan}

Bagian dari maslahah dharuriyah yang harus dilindungi adalah keturunan. Salah satu melindungi keturunan dari keadaan lemah atau kepunahan adalah dengan cara mengikuti program asuransi. Asuransi dirancang untuk melindungi manusia dari risiko-risiko yang kemungkinan akan terjadi di kemudian hari. Peranan asuransi pada kemaslahatan keturunan ini lebih ditekankan pada segi adanya (min nahiyyati al- wujud) yaitu mewujudkan kemaslahatan ahli waris atau keluarga yang ditinggal.

Dengan mengikuti progam asuransi maka keluarga yang ditinggalkan akan masih dapat melanjutkan pendidikan dan melanjutkan kehidupan dengan kondisi ekonomi yang layak. Hal ini selaras dengan perintah Allah untuk tidak meninggalkan keturunan dalam keadaan miskin dan kelaparan dalam surat anNisa ayat 9:

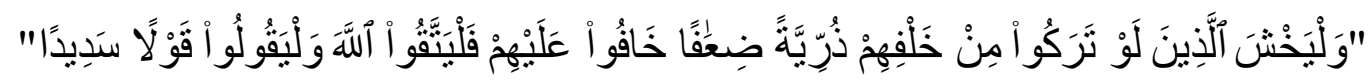

"Dan hendaklah takut kepada Allah orang-orang yang seandainya meninggalkan dibelakang mereka anak-anak yang lemah, yang mereka khawatir terhadap (kesejahteraan) mereka. Oleh sebab itu hendaklah mereka bertakwa kepada Allah dan hendaklah mereka mengucapkan perkataan yang benar".

\section{E. Perlindungan Terhadap Kemaslahatan Harta}

Harta merupakan sesuatu yang harus dilindungi oleh syariah. Segala sesuatu yang berhubungan dengan harta pada umumnya dibahas dalam muamalah. Islam menghalalkan berbisnis untuk memenuhi kebutuhan hidup umatnya. Oleh karena itu bentuk perekonomian seperti jual beli, rahn, mudharabah, musyarakah, dan lain-lainnya menjadi halal. Kegiatan-kegiatan ini termasuk aspek positif (ijabiyyah). Berkaitan dengan aspeknegatif (salbiyah) Islam melarang jual beli yang mengandung unsur riba, tagrir (spekulasi tinggi), tadlis (penipuan), maisir (judi). Salah satu ayat yang melarang aktivitas bisnis dengan cara yang tidak benar misalnya surat al-Baqarah ayat 275 . 


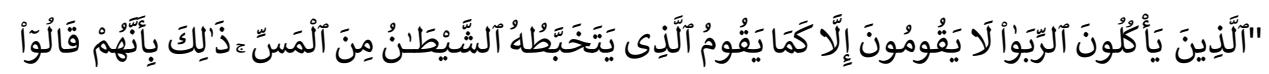

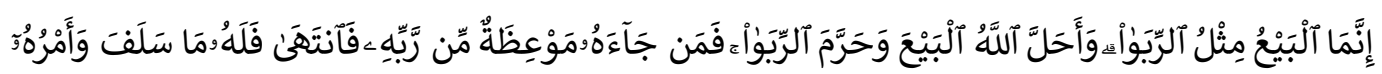

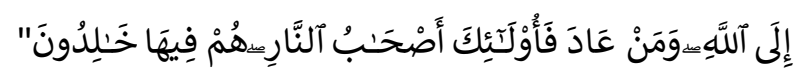

"Orang-orang yang makan (mengambil) riba tidak dapat berdiri melainkan seperti berdirinya orang yang kemasukan syaitan lantaran (tekanan) penyakit gila. Keadaan mereka yang demikian itu, adalah disebabkan mereka berkata (berpendapat), sesungguhnya jual beli itu sama dengan riba, padahal Allah telah menghalalkan jual beli dan mengharamkan riba. Orang-orang yang telah sampai kepadanya larangan dari Tuhannya, lalu terus berhenti (dari mengambil riba), maka baginya apa yang telah diambilnya dahulu (sebelum datang larangan); dan urusannya (terserah) kepada Allah. Orang yang kembali (mengambil riba), maka orang itu adalah penghuni-penghuni neraka; mereka kekal di dalamnya. "

Asuransi yang menangani pada permasalahan ini adalah asuransi kerugian. Maksud dari asuransi ini adalah memberikan jasa dalam penanggulangan risiko atas kerugian, kehilangan manfaat, dan tanggung jawab hukum kepada pihak ketiga yang timbul dari peristiwa yang tidak pasti. Aspek salbiyah dari kemaslahatan harta adalah Islam melarang pencurian, perampokan, dan lain sebagainya. Agar harta terhindar dari hal yang demikian maka hendaknya seseorang mengikuti program asuransi untuk menghindari kerugian yang lebih besar, misalnya mengambil asuransi kebakaran, asuransi kecelakaan mobil, dan lain-lain.

Perlindungan terhadap harta adalah salah satu kebutuhan esensial bagi kehidupan manusia. Kehidupan seperti ini mendorong umat Islam untuk mendapatkan penghasilan yang sah dan halal, yang melarang adanya pendapatan yang bersumber dari pendapatan ilegal sperti perjudian, penyuapan, mencuri, atau apapun yang melibatkan unsur riba. Dengan demikian perlindungan terhadap properti (harta) dikaitkan dengan kegiatan ekonomi termasuk di dalamnya kegiatan asuransi syariah (Abdullah, 2015). 


\section{SIMPULAN}

Sampai saat ini asuransi masih menjadi khilafiah di kalangan ulama. Persoalan kontemporer yang belum ditemukan hukumnya ini menjadi perbincangan hangat. Meskipun demikian, telepas dari boleh atau tidaknya asuransi, studi ini mencoba melihat sisi asuransi dari kaca mata maqasid syariah. Implementasi maqasid syariah pada asuransi merupakan titik temu antara tujuan ditetapkannya syariah. Perlindungan agama dalam asuransi syariah direalisasikan dalam bentuk transaksi yang dimulai dengan kontribusi dalam bentuk tabarru' (donasi). Produk asuransi haji ini tertuang dalam aturan fatwa DSN-MUI No 39/DSN-MUI/X/2002 tentang asuransi haji. Kemudian usaha asuransi syariah dalam aspek perlindungan kemaslahatan jiwa terletak pada hal-hal yang menyebabkan terancamnya jiwa, kerusakan anggota badan yang menyebabkan kecacatan ataupun kematian seseorang. Peranan asuransi pada kemaslahatan jiwa ini lebih ditekankan pada aspek pencegahan (min nahiyyati al- 'adam). Selanjutnya, pada kemaslahatan akal, asuransi tidak secara spesifik melindungi. Namun, salah satu upaya manusia untuk melindungi akal ialah dengan cara menuntut ilmu. Disinilahletak asuransi memainkan perannya sebagai penyandang dana pendidikan. Contoh produk asuransi yang melindungi kemaslahatan akal adalah asuransi takaful dana siswa atau asuransi beasiswa. Dalam perlindungan terhadap keturunan, peranan asuransi lebih ditekankan pada segi adanya (min nahiyyati al- wujud) yaitu mewujudkan kemaslahatan ahli waris atau keluarga yang ditinggal. Terakhir, dalam memberikan perlindungan terhadap harta, asuransi memberikan jasa dalam penanggulangan risiko atas kerugian, kehilangan manfaat, dan tanggung jawab hukum kepada pihak ketiga yang timbul dari peristiwa yang tidak pasti. Contoh asuransi yang melindungi kemaslahatan harta adalah asuransi takaful umum, misalnya takful kebakaran. 


\section{DAFTAR PUSTAKA}

Abdullah, Syahida. (2015). The Objectives of Takaful and Shariah: Towards the Achievement of Maqasid Shariah. Journal of Human Capital Development. Vol. 8 No. 1 January - June

Al-Ghazali. al-Mustashfa. (1997). min Ilm Ushul, Tahqiq Muhammad Sulaiman alAsyqar. Beirut: Al-Resalah.

Ali, AM. Hasan. (2005). Asuransi Dalam Perspektif Hukum Islam (Suatu Tinjauan Analisis Historis, Teoritis, dan Praktis. Jakarta: Prenada Media.

Ali, Zainuddin. (2008). Hukum Asuransi Syariah. Jakarta: Sinar Grafika.

Al-Syatibi, Abu Ishaq. Al Muwafaqat Juz II. Beirut: Dar Al-Ma'rifah. 1997.

Ambarniati. (2017) Tinjauan Hukum Islam terhadap Pengelolaan Dana Peserta Asuransi Syariah di PT Asuransi ASEI Indonesia Cabang Semarang.Semarang: UIN Walisongo.

Departemen Agama RI. (2004). Al-Qur'an dan Terjemahnya Al-Jumanatul 'Ali (Seuntai Mutiara yang Maha Luhur). Bandung: CV Penerbit Jumanatul 'AliArt.

Gemala, Dewi. (2004). Aspek-aspek Hukum dalam Perbankan \& Perasuransian Syari'ah di Indonesia. Jakarta: Prenada Media.

Hafidhuddin Didin, dkk. (2009). Solusi Berasuransi. Bandung: PT Karya Kita. Iqbal, Muhaimin. (2005). Asuransi Umum Syariah Dalam Praktik (Upaya Menghilangkan Gharar, Maisir, dan Riba). Jakarta: Gema Insani.

Ismanto, Kuat. (2016). Asuransi Syariah Perspektif Maqasid Syaraih. Yogyakarta: Pustaka Pelajar.

Jauhar, Ahmad al-mursi Husain. (2010). Maqashid Syariah. Jakarta: Amzah. Mehr dan Cammack. (1981). Dasar-dasar Asuransi, Jakarta: Balai Aksara.

Agusti, Netta. (2019). “Relevansi Asuransi Syari'ah dengan Konsep Maqashid Syari'ah: Telaah Indikator". Saqifah: Jurnal Hukum Ekonomi Syari'ah. 4 (1); 65-74.

Projodikoro, W. (1981) Hukum Asuransi di Indonesia. Jakarta: PT. Intermasa. 
Sula, M. S. Asuransi Syari'ah. (2004). Konsep dan Sistem Operasional. Jakarta: PT. Gema Insani Press.

Warkum Sumitro. (1997). Asas-asas Perbankan Islam dan Lembaga-lembaga Terkait. Jakarta: Raja Grafindo.

Wirdyaningsih. (2005). Bank Dan Asuransi Islam di Indonesia. Jakarta: Prenada Media.

Zaid, M. (1954). Al-Maslahah fi at- Tasyri' al-Islam wa najmuddin at-Tufi. Beirut: Dar al-Fikr. 